\title{
A televisão como arma: projeções sobre modelos de operação e do uso do meio no filme Murder by television (1935)
}

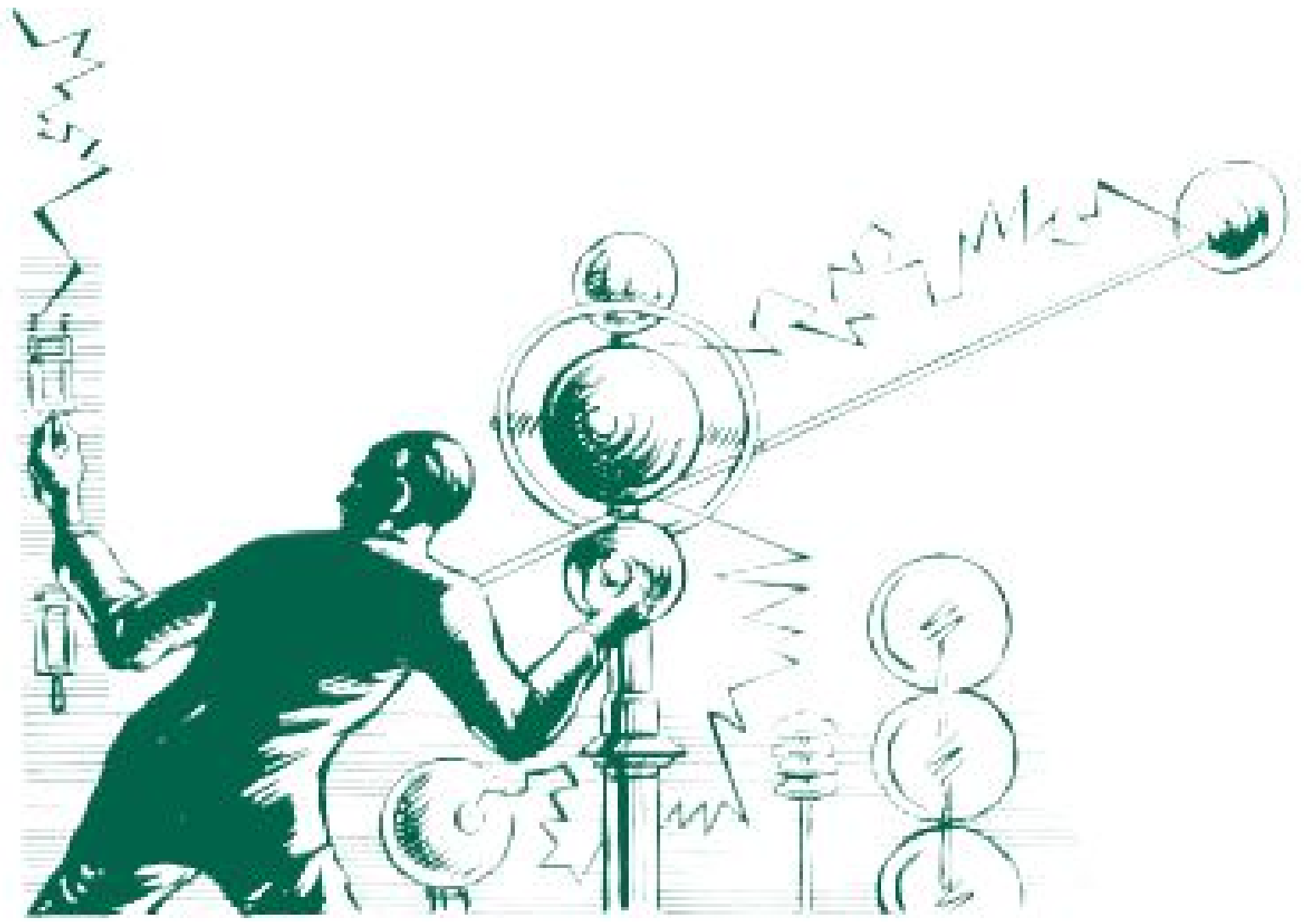

Cartaz de Murder by television, de Clifford Santforth, 1935, fotografia (detalhe).

\section{Áureo Busetto}

Doutor em História Social pela Universidade de São Paulo (USP). Professor do Departamento de História e do Programa de Pós-graduação em História da Universidade Estadual Paulista Júlio de Mesquita Filho (Unesp/Assis). Coorganizador, entre outros livros, de História plugada e antenada: estudos históricos sobre mídias eletrônicas no Brasil. Curitiba: Appris, 2017. a.busetto@unesp.br 


\section{A televisão como arma: projeções sobre modelos de operação e do uso do meio no filme Murder by television (1935)}

Television as a weapon: this medium operation and use models in Murder by television (1935)

\section{Áureo Busetto}

\section{RESUMO}

Busca-se aqui compreender historicamente um filme hollywoodiano de suspense - lançado em 1935 nos EUA e distribuído no Brasil a partir de meados do ano seguinte -, cuja trama apresenta, de forma inusitada, a televisão como arma para assassinato. Nele, pioneiramente, se contempla a disputa de emissoras de televisão e um "governo estrangeiro" pela tecnologia de transmissão de tevê aberta. Ademais, cenas e textos/diálogos de Murder by television expressam, de forma direta ou metafórica, visões e apreciações acerca de modelos de operação e do uso da nascente televisão. Todas engendradas em meio a fatos e processos atinentes à propriedade e ao funcionamento da televisão aberta, bem como à produção e veiculação de seus conteúdos, quer nos EUA quer em alguns países europeus.

PALAVRAS-CHAVE: assassinado pela televisão; tecnologia televisiva; cinema.

\section{ABSTRACT}

Here we try to understand historically a Hollywood suspense film - released in 1935 in the USA and distributed in Brazil from the middle of the following year whose plot presents television as a weapon for murder in an unusual way. In a pioneer way, it contemplates a dispute between television stations and a "foreign government" for open TV transmission technology. Furthermore, scenes and texts/dialogues by Murder by television express, directly or metaphorically, visions and appraisals about operating models and the use of the nascent TV. All of them generated between facts and processes pertaining to the ownership and operation of open television, as well as the production and distribution of its contents, both in the USA and in some European countries.

KEYWORDS: Murder by television; television technology; cinema.

No primeiro dia de outubro de 1935, chegava às telas de cinemas nos EUA Murder by television, filme dirigido por Clifford Santforth, com roteiro de Joseph O'Donnel, com base na história idealizada por Clarence Hennecke e Carl Coolidge, rodado no Talisman Studios (depois chamado de Tiffany Studios), em Sunset Bolleward, produzido pela Cameo Pictures Corporation e com distribuição da Imperial Corporation. ${ }^{1}$ Distribuído sob o título Assassina-

\footnotetext{
${ }_{1}$ Para visualização e decupagem foi utilizada cópia do filme encontrada no YouTube. Disponível em $<$ https://www.youtube.com/watch?v=xW5hvcIJ8gg >. Acesso em 22 set. 2019.
} 
do pela televisão, o filme de Santforth estreou no Brasil em agosto de 1936. Inscrito no gênero suspense, ele gira em torno da descoberta do assassinato de professor que inventou inovadora tecnologia televisiva e se recusava a comerciá-la. Quando da demonstração de sua tecnologia, o professor é assassinado em frente às câmeras de tevê, com raio mortal emitido via aparelhagem televisiva. Murder by television está longe de ser o primeiro filme a exibir cenografia relativa à aparelhagem televisiva ou ostentar no título o termo televisão. Mas é o pioneiro a enfocar, ao mesmo tempo, disputa comercial e de "governo estrangeiro" por tecnologia de televisão aberta, além de conter cenas exibindo aparelhagem real de transmissão televisiva. Sem desconsiderar ter sido o primeiro e único, por décadas, a projetar à televisão a função de arma letal.

Se durante as duas primeiras décadas do século $X X$ fora produzido pequeno conjunto de filmes a exibir dispositivos dotados de tecnologia televisiva em suas tramas², a partir dos anos de 1920 a exibição cenográfica deles cresceria relativamente nos roteiros de filmes de Hollywood e do cinema europeu. Tecnologia, em regra, acoplada a telefones, telescópios e rádios ou a funcionar como circuito fechado de tevê. Conjunto de filmes que se aproximava do mundo da ciência e técnica, uma vez que protótipos de telefone com imagens e de aparelhos de televisão mecânica eram buscados naqueles dois âmbitos; sem, contudo, prosperarem em termos de industrialização. Entretanto, dispositivos que eram, em regra, cenograficamente montados pouco conformes ao nível técnico alcançado e designs existentes da aparelhagem televisiva quando da produção dos filmes. Tais representações cenográficas eram fruto da criatividade ou fantasia de escritores, roteiristas, cenógrafos de cinema, além de serem, quase sempre, montados com material de qualidade precária. Mas viriam, também, a lume, ainda nos anos de 1920, alguns poucos filmes a projetarem noções sobre a operação da tevê aberta, adiantando-se ao que ocorreria em meados da década seguinte. A partir daí, a televisão como meio de comunicação social figuraria em roteiros de alguns filmes.

Fora a partir da década de 1920 que chegara ao público brasileiro filmes que integravam a tecnologia televisiva em seus roteiros, dado o crescimento da produção e distribuição internacional de filmes em geral. Entretanto, no país a distribuição de filmes de Hollywood se tornava preponderante, aliás, como em tantas outras partes do mundo. Durante as décadas de 1920 e 1930, a maior produção do cinema hollywoodiano tinha à frente cinco grandes companhias: Metro-Goldwyn-Mayer, Paramount, 20th Century Fox, Warner Bros. e RKO, seguidas, à época, com grande distância por três outras pequenas: Universal, Columbia e United Artists. No fim da ponta do sistema se encontravam companhias tocadas com modestos orçamentos, como a Cameo Pictures, responsável pela produção de Murder by television, além de Mascot, Monogram, Liberty Films, Studio City, Chesterfield Pictures e Invincible Pictures. Essas seis últimas formariam, em 1935, a Republic Pictures, corporação ocupada em acelerar à produção e distribuição dos chamados Filmes B ou

\footnotetext{
2 Ver KOSZARKI, Richard and GALILI, Doron. Television in the cinema before 1939: an international annotated database. Journal of e-Media Studies, v. 5, n. 1, Hanover, 2016. Disponível em <https://journals .dartmouth.edu/cgi-bin/WebObjects/Journals.woa/1/xmlpage/4/article/471>. Acesso em 5 ago. 2019.
} 
"caça-níqueis". ${ }^{3}$ Filmes a exibir tecnologias televisivas ou noções sobre tevê aberta eram mormente produzidos por tais modestas companhias. ${ }^{4}$

De maneira ampla ou restrita, explícita ou implicitamente, a maioria dos motes, conjunturas e projeções a envolver a tecnologia televisiva e TV aberta - fossem em filmes lançados antes, fossem logo posteriormente à distribuição de Murder by television - compõe o roteiro/enredo do único filme a apresentar, no período, a televisão como arma para um assassinato. E ainda que a sua trama se desenrole sob o gênero suspense, o roteiro do filme contempla elementos de romance, comédia, musical e, mesmo, ficção científica. Gêneros em que se inscreviam filmes a exibir tecnologia televisiva nos anos 1920 e 1930.

Filmes produzidos no decorrer da década de 1920 posicionavam, em regra, a tecnologia televisiva a serviço do crime ou no combate deste. Espelhavam de certa maneira o período de intensificação da atuação de gângsteres nas duas partes do Atlântico Norte, sobretudo nos EUA com a vigência da Lei Seca. São os casos de The thirteenth hour (de 1927, dirigido por C. Franklin, da Metro - no Brasil distribuído sob o título $O$ abutre noturno, lançado em março de 1928); The third eye (1929, M. Rogers, Graham-Wilcox); The lone wolf's daughter (1929, A. S. Rogell, Columbia - Atração do alheio, outubro de 1929). ${ }^{5} \mathrm{E}$ tal tendência se manteria ao longo dos anos 1930, notadamente com filmes formatados como seriados, muitas vezes com personagens cientistas a se valer da tecnologia televisiva, alguns deles insanos. São exemplos: Whispering shadow (1933, C. Clark e A. Herman, Mascot - A visão fatal, outubro de 1934); The miracle rider (1935, B. R. Eason e A. Schaefer, Mascot - O cavaleiro alado, março de 1937); The fighting marines (1935, B. R. Eason e J. Kane, Mascot - Guerreiros da marinha, agosto de 1937); Werewolf of London (1935, S. Walker, Universal - O lobisomem de Londres, dezembro de 1935), Shadow of Chinatown (1936, R. Hill, Victory Pictures - O mistério do bairro chinês, dezembro de 1937), The Amazing exploits of the clutching hand (1936, A. Herman, Weiss Productions - A mão que aperta, outubro de 1936); Blake of Scotland Yard (1937, R. Hill, Victory Pictures A sombra do escorpião, janeiro de 1938); e The phantom creeps (1939, F. Beebe e S. Goodkind, Universal - A sombra destemida, abril de 1940). ${ }^{6}$

Embora na trama de Murder a tecnologia televisiva estivesse nas mãos de cientista bem intencionado e são mentalmente - o professor James Houghland (Charles Hill Mailes) -, a posse dela é disputada por terceiros via estratégias ilícitas. Assim, o personagem Edwin Perry que, afeito ao crime e irmão gêmeo de outro personagem - Arthur Perry (em dupla interpretação de

\footnotetext{
${ }^{3}$ Ver LIPOVETSKY, Gilles e SERROY, Jean. A estetização do mundo: viver na era do capitalismo artista. São Paulo: Companhia das Letras, 2015, p. 195 e 196, e Republic - Duke Movie \& Backlots. Disponível em $<$ https://dukewayne.com/index.php?thread/5025-republic/>. Acesso em 28 fev. 2020.

${ }^{4}$ Dado o quadro da distribuição cinematográfica no Brasil dos anos 1920 e 1930, neste artigo são enfocados filmes de Hollywood a contemplar tecnologias televisivas ou da tevê aberta exibidos ao público brasileiro. Entretanto, vez ou outra, serão enfocados, para efeito narrativo-explicativo-argumentativo, filmes europeus, distribuídos ou não no Brasil, e hollywoodianos que não chegaram aos cinemas brasileiros.

${ }^{5}$ Ver KOSZARKI, Richard and GALILI, Doron, op. cit., edições de jornais e revistas de várias localidades publicadas nos períodos de mar. 1928-nov. 1929 e out. 1929-jan. 1930. Disponíveis no acervo da Hemeroteca Digital da Biblioteca Nacional.

${ }^{6}$ Ver KOSZARKI, Richard and GALILI, Doron, op. cit., edições de jornais e revistas de várias localidades publicadas no período de mar. 1937-out. 1940. Disponíveis no acervo da Hemeroteca Digital da Biblioteca Nacional.
} 
Bela Lugosi) - se vale de impostura para tentar roubar, a mando de executivo de uma emissora de tevê, o segredo da tecnologia inovadora. Vinculado a outra emissora, o personagem Richard Grayson (George Meeker) se coloca a espionar o segredo da tecnologia, mesmo sendo namorado de June Houghland (June Collyer), filha do professor/inventor. E o personagem Dr. Scofield (Huntley Gordon), que, apresentado como "pesquisador do cérebro" e amigo do professor Houghland, atua como agente secreto de "governo estrangeiro", com vistas a obter a tecnologia disputada.

Existe um conjunto de filmes a posicionar o uso da tecnologia televisiva em futuro não muito longínquo em relação ao período de suas produções ou investindo na noção de que tal tecnologia seria introduzida imediatamente no cotidiano das pessoas. Na primeira chave, há o caso excepcional da ficção científica The tunnel (1935, M. Elvey, Gaumont British - Túnel transatlântico, maio 1936), trama que, desenrolada na década de 1950, enfoca construção de túnel submarino a ligar Europa e EUA, contemplando cenas com tela, em praça pública, a televisionar etapas daquela construção e o uso de telefone com imagens por personagens. Sua história, uma adaptação do romance homônimo de Bernahard Kellerman, já dispunha de duas outras versões fílmicas alemãs: Der tunnel (1915, Willian Wauer, Projektions-AG); e Le tunnel (1933, Kurt Bernhardt, UFA - Túnel submarino, estreado no Brasil somente em novembro de 1947), versão em francês rodada em Munique. ${ }^{7}$ Bem antes, o cinema italiano trazia a público a ficção científica L'uomo meccanico - idealizada, dirigida e com atuação do francês Andre Deed, produzida para a Milano Film e lançada em 1921. Sua trama, desdobrada no então presente vivido, exibe dois gigantescos autômatos teleguiados por espécie de aparelho de TV. Sob o título $O$ homem mecânico, o filme de Deed fora exibido apenas em cinemas paulistanos em julho de 1929; coincidentemente, protótipos de robôs eram apresentados ao mundo. ${ }^{8}$

E alguns filmes tratariam a inclusão da tecnologia televisiva no futuro mais ou menos próximo. Sob enredos divertidos, há os hollywoodianos: The last man on earth (1924, J. G. Blystone, Fox - O último varão da terra, março de 1925), comédia/ficção científica cuja trama se passa entre 1940 e 1954, exibindo grande tela a transmitir publicamente notícias e televisor de parede; e Just imagine (1930, D. Butler Fox - Fantasias de 1980, maio de 1931), comédia musical de ficção científica, ambientada em uma Nova York futurista de 1980, com cena de jovens utilizado o telefone com imagens para se comunicarem. Com enredo circunspecto, há dois filmes, um britânico e outro hollywoodiano, a centrarem-se em tramas que se desenrolam no ano de 1940, às vésperas de imaginados conflitos bélicos mundiais. São eles: High treason (1929, M. Elvey, Gaumont-British - exibido com igual título apenas no carioca Serrador, fevereiro de 1930), com uso do telefone com imagem para comunicação interpessoal e tentativa de uso do aparelho pelo presidente do fictício Estados Unidos da Europa para emitir declaração de guerra ao igualmente Império dos Esta-

\footnotetext{
7 Ver KOSZARKI, Richard and GALILI, Doron, op. cit., edições de jornais e revistas de várias localidades publicadas, respectivamente, nos períodos de maio 1936-jun. 1938 e nov. 1947-fev. 1948. Disponíveis no acervo da Hemeroteca Digital da Biblioteca Nacional.

${ }^{8}$ Ver KOSZARKI, Richard and GALILI, Doron, op. cit., edições de jornais e revistas de várias localidades publicadas entre jan. 1928-jun. 1929. Disponíveis no acervo da Hemeroteca Digital da Biblioteca Nacional.
} 
dos Atlânticos; e Men must fight (1933, E. Selwyn, Metro - Lição ao mundo, junho de 1933), trama desenrolada sob clima de declaração de guerra dos EUA a fictício país da Eurásia, com exibição de vídeo-telefone e transmissão de TV em prol da paz. ${ }^{9}$

No desenrolar da trama de Murder o funcionamento da tevê aberta e a sua transmissão ao vivo em âmbito nacional e imagens de partes do mundo são posicionadas como realidade de meados dos anos 1930, como atesta um take de cena final do filme a exibir, em close, um telegrama datado de 3 de janeiro de 1935. Assim, o seu roteiro projeta emissões televisivas regulares como algo já posto nos EUA. Tanto que contempla na trama a operação de duas emissoras de TV quanto personagens vinculados a ambas: a CMP Television Corporation, integradas pelos personagens Hammond (Henry Hall) e o já mencionado Richard Grayson; e a Continental Television Corporation, com os personagens Donald Jordan (Charles K. French) e o anteriormente citado Arthur Perry. Entretanto, na realidade aquele feito se daria apenas em meados de 1939, quando entrava em funcionamento a emissora comercial National Broadcasting Company (NBC). Mas o meio já era operado regularmente na Alemanha, desde 1935, via Centro Nipkow, e seria na Grã-Bretanha em 1936, com a emissora pública British Broadcasting Corporation (BBC). A tecnologia de transmissão televisiva inventada pelo professor Houghland, possibilitando transmissão ao vivo em âmbito nacional e internacional, não encontrava nenhum paralelo na realidade daquele período. Ela se tornaria possível apenas com o advento de satélites artificiais, conquista técnico-científica ocorrida nos anos de 1960. E Murder, assim como os dois últimos filmes acima enunciados, conta com o empenho de personagem em empregar a tecnologia televisiva a serviço do bem comum e da paz mundial. O filme contempla, como vários outros até aqui enfocados, a interface entre a tecnologia televisa e a telefônica - a qual possibilita o disparo do raio mortal, via tevê, a assassinar Houghland -, bem como dialogo em que se aventa o emprego daquela tecnologia no combate ao crime em substituição à comunicação policial feita pelo rádio.

Ainda no gênero ficção científica, há filmes de aventura que projetavam o uso da tecnologia televisiva a civilizações extraterrestes ou de lugares recônditos na Terra. Como era o caso de Radio-Mania (1922, R. W. Neill, Teleview e Hodkinson - Radio-Mania, agosto de 1923), com habitantes de Marte a disporem de aparelhagem de tevê. ${ }^{10} \mathrm{E}$ tal tendência ganhou vulto no decorrer dos anos de 1930, mesmo que a televisão aberta estivesse prestes a se tornar possível ou já fosse realidade para alguns terráqueos de metrópoles ocidentais. São exemplos de tal tendência fílmica: The phantom empire (1935, O. Brower e B. Eason, Mascot - O império dos fantasmas, fevereiro de 1937); The lost city (1935, H. Revier, Sherman S. Krellberg - Cidade infernal, setembro de 1937); Undersea kingdom (1936, B. R. Eason, Republic - O império submarino, fevereiro de 1937); Flash Gordon (1936, F. Stephani, Universal - com igual título no Brasil, junho de 1936); Flash Gordon's trip to Mars (1938, F. Beebe e R. Hill, Univer-

\footnotetext{
${ }^{9}$ Ver KOSZARKI, Richard and GALILI, Doron, op. cit., edições de jornais e revistas de várias localidades publicadas entre mar.-out. 1925 e jun. 1933-fev. 1934. Disponíveis no acervo da Hemeroteca Digital da Biblioteca Nacional.

${ }^{10}$ Ver KOSZARKI, Richard and GALILI, Doron, op. cit., Para Todos, 29 ago. 1923, Folha da Manhã, 11 out. 1924, e O Dia, 13 mar.1925.
} 
sal - Flash Gordon no planeta Marte, setembro de 1938); Buck Rogers (1939, F. Beebe, Universal - igual título no Brasil, agosto de 1939). ${ }^{11}$

Na trama de Murder tem-se uma tênue ilação ao risco que sociedades tidas como livres/democráticas pudessem correr caso a tecnologia televisiva fosse dominada por forças políticas tirânicas e/ou totalitárias, tal como demarcado, de forma fantasiosa, no conjunto de filmes destacados acima. Esses provavelmente refletiam a ascensão ao poder do nazifascismo, na Alemanha, e do stalinismo, na URSS; governos já conhecidos pelo controle social repressivo e sistemática propaganda político-ideológica. Ademais, Murder contempla dose de ficção científica. $\mathrm{O}$ raio mortal a atingir o professor Houghland não é de natureza terrestre, mas, sim, de "frequência de ondas interestelares".

Mesmo que a tecnologia televisiva fosse empregada, nos roteiros fílmicos, principalmente como meio de vigilância nas mãos de vilões, fossem humanos ou não, ela fora projetada para vigiar o trabalho fabril em Modern times, o clássico filme de Charles Chaplin (1936, United Artists - Tempos modernos, maio de 1936). Na antológica sequência do filme em que o personagem de Chaplin trabalha numa fábrica, há a cena em que ele, ao se refugiar no banheiro da veloz, repetitiva e extenuante linha de montagem, é flagrado, via circuito fechado de TV, pelo presidente da empresa. ${ }^{12}$ Se o filme de Chaplin posiciona, de forma peculiar, a tecnologia televisiva a serviço da extração do lucro privado pela alienante produção industrial em série, em Murder o professor Houghland recusa-se a vender seu invento às emissoras comerciais de TV aberta, essas visando apenas ao lucro privado em detrimento aos interesses da coletividade.

No quadrante da ficção científica a contemplar tecnologia televisiva em distopias processadas em futuro longínquo destacam-se dois grandiosos filmes, ambos europeus. O clássico expressionista alemão Metropolis, de Fritz Lang (1927, UFA - veiculado com o mesmo título no Brasil, outubro de 1928), cuja trama, desenrolada no ano 3.000, exibe o poderoso senhor do mundo acima do solo a se comunicar via Picturephone com as oficinas de máquinas localizadas no subterrâneo, além de televisionamento público do governante tirano em tela gigante. Murder, ao contemplar a busca desmedida de "governo estrangeiro" pela tecnologia televisiva inventada por Houghland, indica, ainda que indireta e fluidamente, a intenção daquele governo empregar a televisão para controle social repressivo e/ou propaganda política, como será detalhado na última parte deste artigo. Mas ao contrário do filme de Lang, o hollywoodiano posiciona tal uso nefasto como possível nos anos de 1930. E há o filme britânico Things to come (1936, W. C. Menzies, London Film - Daqui a cem anos, fevereiro de 1937), cuja trama, baseada no livro homônimo H. G. Wells, enfoca o mundo dividido, após longo período de guerra, no decorrer de meados do século XXI, contemplando cenas com televisor doméstico (chamado "aparelho no qual as imagens aparecem"), com veiculação apenas de conteúdo educativo-cultural, além de transmissões públicas de imagens televisivas

\footnotetext{
${ }^{11}$ Ver KOSZARKI, Richard and GALILI, Doron, op. cit., edições de jornais e revistas de várias localidades publicadas entre fev. 1937-mar.1941. Disponíveis no acervo da Hemeroteca Digital da Biblioteca Nacional.

${ }^{12}$ Ver KOSZARKI, Richard and GALILI, Doron, op. cit., edições de jornais e revistas de várias localidades publicadas entre maio 1936 e set. 1940. Disponíveis no acervo da Hemeroteca Digital da Biblioteca Nacional.
} 
em tela enorme disposta em lugares públicos. ${ }^{13}$ No computo de alguns textos/diálogos no desenrolar da trama de Murder é indicada a preferência do professor Houghland pela veiculação de programas televisivos defendidos no filme britânico, ou seja, conteúdo televisivo voltado à difusão do conhecimento. Perspectiva que, aliás, era consonante ao caminho que a nascente e pública BBC seguiria no outro lado do Atlântico Norte.

Centrados na realidade então vivida, há filmes que demarcam a influência da tecnologia televisiva na vida íntima das pessoas. Destaca-se, nessa chave fílmica, Up to ladder (1923, E. Sloman, Universal - Quando a felicidade sorri, junho de 1925), drama em que o inventor do Televisionscope (telefone com imagens) tem sua infidelidade conjugal revelada via chamada de sua esposa pelo tal aparelho. Richard Koszarski considera que tal filme talvez possa ter sido o primeiro a demarcar nitidamente a tecnologia televisiva como elemento a influir na trama, além de salientar que o roteiro do filme é incomum para a época, uma vez que tal tecnologia é posicionada "fora de uma estrutura fantasiosa ou de ficção científica" ${ }^{14}$ Em Once a sinner (1931, G. McClintic, Fox Escrava do passado, agosto de 1931), também um drama romântico com triângulo amoroso, envolvendo inventor de rádio dotado de tecnologia televisiva, com o qual ele capta imagens da intimidade de outros personagens..$^{15}$ Se o roteiro de Murder não aborda os riscos de a tecnologia televisiva influir na vida íntima das pessoas, ele enfoca, ainda que de forma metafórica, o perigo que poderes mercantis e políticos desmedidos pudessem causar à formação da consciência individual; como será detalhado adiante.

A corrida comercial pela tecnologia televisiva, quer pela via legal ou por meios escusos, serviu de mote a alguns filmes, como, por exemplo, os hollywoodianos: International house (1933, E. Sutherland, Paramount - Torre de Babel, outubro de 1934), comédia em que inventor chinês do Radioscópio dispositivo a transmitir filmes e programas televisivos - promove demonstrações na China para interessados na compra do invento; Television spy (1939, E. Dmytryk, Paramount - Espionagem por televisão, junho de 1940), jovem inventor que, patrocinado por investidor rico, cria sistema de TV e objetiva entregálo ao governo dos EUA, mas espiões tentam ilicitamente se apossarem da tecnologia. ${ }^{16}$ A trama de Television guarda proximidade à de Murder, entretanto os objetivos do jovem inventor e do professor Houghland são diferentes: o primeiro, movido por patriotismo, pretende entregar seu invento ao governo de seu país; o segundo, de maneira altruísta, dispô-la "gratuitamente a todos os povos". Em comparação às tramas de International e Murder, a diferença se

\footnotetext{
13 Ver KOSZARKI, Richard and GALILI, Doron, op. cit., p. 12, 31 e 32, edições de jornais e revistas de várias localidades publicadas, respectivamente, nos períodos de maio 1928-fev. 1931 e fev. 1937-set. 1939. Disponíveis no acervo da Hemeroteca Digital da Biblioteca Nacional.

${ }^{14}$ KOSZARSKI, Richard. Coming next week: images of television in Pre-War Motion Pictures. Film History, v. 10, n. 4, Bloomington, 1988, p. 130 e 131 (tradução livre). Ver Leitura para Todos, abr.1923, Pelo Mundo, out. 1923, Scena Muda, 4 dez. 1924, Ilustração Moderna, 21 fev. 1925, Fon-Fon, 11 jun.1925, Folha da Manhã, 11 jun. 1925, e Para Todos, 13 jun. 1925.

15 Ver KOSZARKI, Richard and GALILI, Doron, op. cit., edições de jornais e revistas de várias localidades publicadas entre de ago. 1931-nov.1932. Disponíveis no acervo da Hemeroteca Digital da Biblioteca Nacional.

16 Ver KOSZARKI, Richard and GALILI, Doron, op. cit., Folha da Manhã, 11 set. 1940, edições de jornais e revistas de várias localidades publicadas no período de out. 1934-jun. 1936 e set. 1940-mar.1941. Disponíveis no acervo da Hemeroteca Digital da Biblioteca Nacional.
} 
estabelece no interesse comercial com a tecnologia televisiva pelos seus criadores, cuja venda é buscada pelo inventor chinês e recusada por Houghland. Contudo, há um elemento comum nos seus roteiros: a nacionalidade chinesa de personagens interessados na tecnologia televisiva. No primeiro filme, tratase do próprio protagonista/inventor, no segundo, o personagem coadjuvante Ah Ling (Allen Jung), jovem chinês a servir à família de Houghland como mordomo, mas integrando grupo de intercambiários da China nos EUA para aprofundamento tecnológico da tevê, elemento da trama a refletir a realidade, pois intercambiários chineses eram recebidos nos EUA em vários ramos do saber desde o último terço do século XIX.17

Noções sobre TV aberta ganham espaço em alguns roteiros de filmes produzidos já nos anos 1920. Assim, há o notório filme francês L'inhumaine, de Marcel Herbie (1924, Cinégrafic), com cena de aparelhagem televisa e transmissão de número musical de personagem cantora para várias regiões do mundo. Sem distribuição deste drama no Brasil, o público local era informado da participação do brasileiro Alberto Cavalcanti na equipe de cenografia do filme. ${ }^{18} \mathrm{E}$ há a lapidar comédia curta Uncle si and the sirens (1928, direção desconhecida, CineArt Productions), cujo protagonista capta, via televisor, consecutivamente, conferência de professora de etiqueta, dança ao som da HulaHula e imagens de mulheres nuas; essas enfurecendo a sua esposa, a qual acaba por esmagar o marido e o televisor com uma vassoura. Koszarki considera Uncle si como o primeiro filme a tratar a disciplina televisiva em termos de veiculação e consumo de conteúdo. ${ }^{19} \mathrm{E}$ nessa direção há, também, The singing cowboy (1936, M. Wright, Republic - O cowboy cantor, abril de 1938), musical/western com banda musical intitulada Trovadores da Televisão em turnê pelos EUA, transmitindo, em grande tela, programas televisivos de distintos gêneros. ${ }^{20}$ Ao exibir anúncio de marca de café, patrocinadora da caravana, o filme expõe a relação televisão aberta/publicidade; tal como ocorria com o rádio nos EUA.

E, por fim, há filmes cujos roteiros projetam esboços de programas televisivos, embora na realidade existissem poucos exemplos deles a servirem de modelos a escritores e roteiristas de cinema. Da Grã-Bretanha viriam Elstree calling (1930, A. Charlot, J. Hulbert, P. Murray e A. Hitchcock, British Intl.), e Radio parade of 1935 (1934, A. B. Woods, Associated British Pictures - no Brasil exibido com título original em mostra de filmes europeus, maio de 1935). E do cinema de Hollywood sairiam Believe it or not no. 4 (1930, A. Hurley, Warner Parece incrível, outubro de 1932); The big broadcast of 1936 (1935, N. Taurog, Paramount - Ondas sonoras de 1936, maio de 1936); Manhattan merry go-round (1937, C. F. Riesner, Republic - Artistas em folia, maio de 1939); e Five of a kind

\footnotetext{
17 Ver HSU, Madeline Y. Chinese and american collaborations through educational exchange during the era of exclusion, 1872-1955. Pacific Historical Review, v. 83, n. 2, Oakland, 2014.

${ }^{18}$ Ver KOSZARKI, Richard and GALILI, Doron, op. cit., p. 11, Fon-Fon, 17 nov. 1923, Paratodos, 2 fev.1924, A Cigarra, abr.1925, e Cinearte, 2 jun.1926.

${ }^{19}$ Cf. KOSZARSKI, Richard, op. cit.

${ }^{20}$ Ver KOSZARKI, Richard and GALILI, Doron, op. cit., p. 33 e 34, edições de jornais e revistas de várias localidades publicadas entre abr. 1938-nov. 1939. Disponíveis no acervo da Hemeroteca Digital da Biblioteca Nacional.
} 
(1938, direção desconhecida, Fox - Cinco do mesmo naipe, fevereiro de 1939).. ${ }^{21}$ Nesses filmes, em regra, os programas televisivos eram adaptações da programação radiofônica; aliás, como ocorreria de fato até os anos 1950.

Como salientado acima, o professor Houghland manifesta preferência de que a programação veiculada pela televisão aberta fosse voltada à difusão do conhecimento. Tanto que, quando da sua demonstração televisiva, ele transmite imagens de lugares e povos de algumas partes do mundo. Esboços de expedientes que caracterizam os gêneros telejornalismo e teledocumentário, ou seja, o par voltado para divulgar informação e conhecimento, respectivamente. Mas há, também, espaço ao entretenimento na tevê almejada por Houghland. Afinal, ele televisiona número musical, com apresentação da singela canção "I had the right idea" (letra e música de Oliver Wallace), sob execução de uma pianista e a interpretação da sua filha. Logo, entretenimento voltado à família.

Se o inusitado crime anunciado no título de Murder funcionara como atrativo ao grande público, a divulgação do suspense se dera, também, com base na promoção de sua outra particularidade: a exibição de aparelhagem real de transmissão da tevê aberta.

\section{Entre o divulgado e o exibido na tela}

A curiosidade das pessoas em saber sobre a televisão, aguçada desde o final dos anos 1920 pela imprensa, não passara despercebida aos agentes envolvidos com a produção de Murder by television. Tanto que o seu release de divulgação nos EUA ressalta: “Todo mundo já ouviu falar sobre televisão; todo mundo fala sobre televisão; e mesmo assim poucos já viram ela funcionar". ${ }^{22} \mathrm{O}$ filme, então, oferecia ao público um triplo mistério a ser revelado: autoria e motivo do assassinato anunciado no título; maneira como a televisão servira de arma para tal crime; e, prendendo-se à realidade, o funcionamento técnico da tevê aberta. No entanto, parece que tal noção não estava totalmente interiorizada pela equipe de produção do filme quando da escolha do seu título provisório: The Houghland's murder case. Mas a ideia de promover o filme se valendo da curiosidade geral sobre a televisão englobou interessante estratégia de atração à bilheteria. A distribuidora do Murder incentivara proprietários de cinemas nos EUA a alugarem um televisor para expô-lo ao público. ${ }^{23}$

Contudo, o título definitivo do filme constituía-se, por si só, em potente atrativo de bilheteria. A certeza de que assim funcionasse deve ter pesado na elaboração do cartaz de Murder, uma vez que nenhuma imagem de aparelhagem televisiva, nem mesmo de televisor, fora estampada nele; como podese observar na figura 1. Se a impressão da palavra televisão com letras no formato de raios estilizados pode ser tomada como representação gráfica das ondas hertzianas a trafegarem pelo espaço eletromagnético, ela, entretanto, representa graficamente o "raio mortal interestelar" emitido para o assassina-

\footnotetext{
${ }^{21}$ Ver KOSZARKI, Richard and GALILI, Doron, op. cit., edições de jornais e revistas de várias localidades publicadas no período de out. 1932-dez. 1940. Disponíveis no acervo da Hemeroteca Digital da Biblioteca Nacional.

${ }^{22}$ KOSZARSKI, Richard, op. cit., p. 134 (tradução livre)

${ }^{23}$ Idem.
} 
to da trama. Leitura plausível quando se observa o desenho disposto na parte inferior do cartaz em que é visto homem operando uma engenhoca a emitir raios, a qual não guarda nenhuma semelhança à aparelho televisivo então existente e, mesmo, ao exibido no filme.

Notável é o destaque dado no cartaz ao nome e a figura do astro maior do elenco do filme: Bela Lugosi. Reconhecido ator de filmes do gênero terror que, dentre outras interpretações, encarnara o personagem-título do mundialmente visto Drácula (de 1931, Tod Brownig, Universal), Lugosi vivia certo ocaso de sua carreira; situação que o levara a aceitar papéis em Filmes B, quase sempre com interpretações de qualidade questionável. Antes de Murder, o ator tinha encarnado personagens às voltas com a tecnologia televisa em Whispering shadow e International house. Após o suspense do assassinato pela TV, Lugosi protagonizaria dois outros seriados a empregar tecnologia televisiva: Shadow of Chinatown e The phantom creeps, lançados nos EUA, respectivamente, em 1936 e $1939^{24}$ (filmes distribuídos no Brasil, como assinalado anteriormente). $\mathrm{O}$ ator símbolo dos filmes de suspense/terror parecia ter sua imagem colada aos mistérios/receios que envolviam o funcionamento da TV no decorrer dos anos 1930.

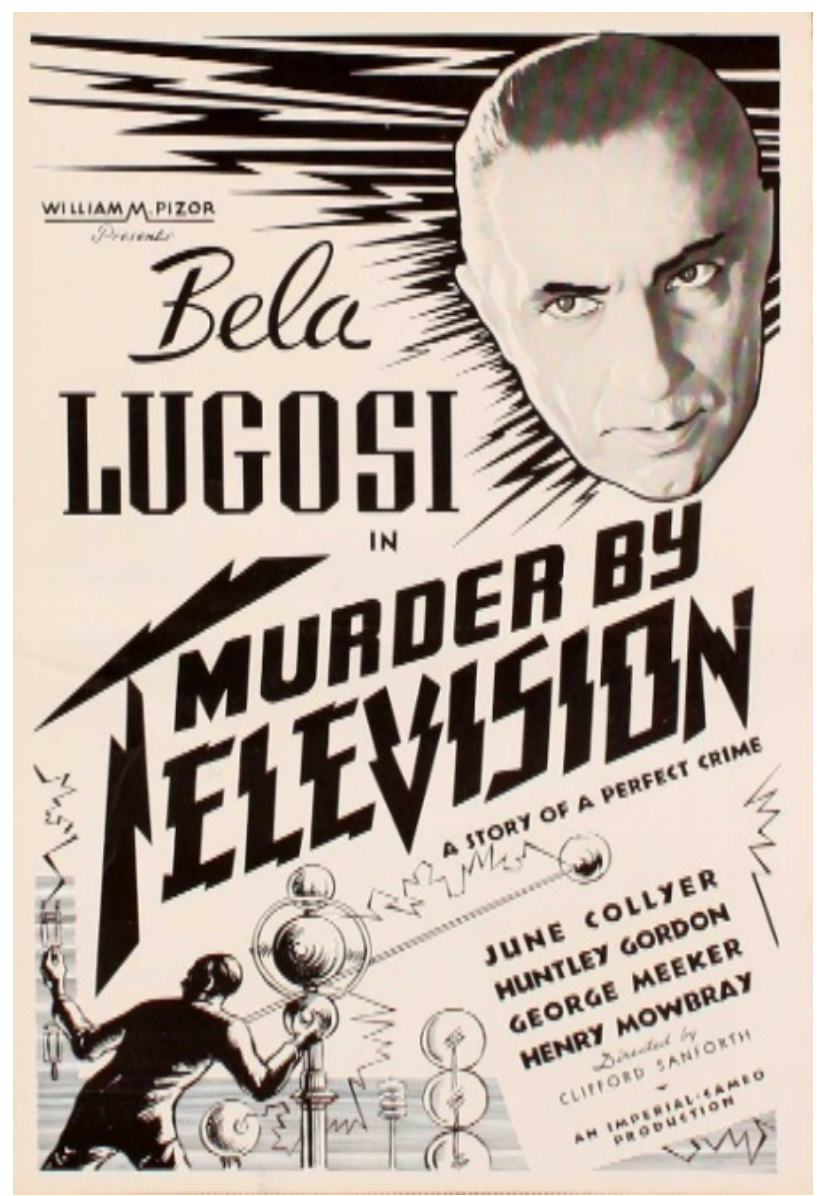

Figura 1. Cartaz de Murder by television.

\footnotetext{
${ }^{24}$ Segundo fichas técnicas dos filmes mencionados contidas no site Internet Movie Database (IMDb). Disponível em < https://www.imdb.com/>. Acesso em 6 fev. 2020.
} 
A divulgação na imprensa brasileira de Assassinado pela televisão oscilou entre promovê-lo em matérias com chamadas à atuação de Bela Lugosi ou ao crime executado via televisão. Contudo, algumas matérias destacavam em seus textos a exibição de cena do filme que apresentava a TV em funcionamento. Todas, porém, estampavam títulos que abusam da nota demagógica acerca do desempenho do astro maior do filme e do sensacionalismo para anunciar o inusitado crime da trama: "Bela Lugosi na mais surpreendente das suas caracterizações"; "O filme máximo de Bela Lugosi"; "O mais espantoso filme com Bela Lugosi"; "Uma nova modalidade de crime"; "A luz mensageira da morte"; "O crime científico provado". E propagandas, ao anunciarem lançamento do filme, seguiam na mesma direção: “A mais espantosa criação de Bela Lugosi - o 'az' do terror"; “Um filme de emoções violentas que mostra o que realmente é a televisão, maior invento do século"; “A polícia impotente para deter a televisão que tudo atravessa e nada a controla"; "Um drama de palpitante atualidade com Bela Lugosi - o horripilante Drácula!”; “O trabalho máximo de Bela Lugosi (O Drácula)"; "Impressionante filme com Bela Lugosi, assassino científico sem deixar traços". ${ }^{25}$

Dada a reprodução de iguais conteúdos textuais, apesar de uma ou outra pequena alteração nos seus títulos, matérias ocupadas em noticiar o filme Assassinado, publicadas em variados periódicos de diferentes localidades, deixam transparecer que se baseavam ou eram simples cópia de possível release fornecido pela distribuidora do filme. Algumas destacavam o cerne do suspense focalizado pelo filme, sem deixarem de reforçar a diferenciada forma de execução do assassinato e o fato de ela ser possível graças à ciência e/ou ao invento da televisão. Nesse sentido, eram expressados comentários como "Clifford Sanforth dirigiu essa produção que mostra modalidade de crime e o tipo de criminoso moderno que se socorre da ciência para realizar seus planos diabólicos"; "A descoberta da televisão, que constitui uma das maiores preocupações do momento, foi aproveitada de forma completa pelo cérebro de malfeitor para a prática dos seus crimes"; "[O filme] Apresenta a televisão como instrumento do criminoso"; "Esta película cheia de imprevistos mostra como parte essencial as maravilhas da televisão, julgado até bem pouco uma quimera e hoje é uma indiscutível realidade, que servindo como instrumento em mãos criminosas roubou a vida do cientista que havia descoberto os seus segredos". ${ }^{26}$

Publicado sob variados títulos quando do lançamento de Assassinado em capitais estaduais, o texto jornalístico chama a atenção por conter um trecho totalmente decalcado da realidade brasileira: "Se até hoje, você não pensou em comprar um aparelho de televisão, provavelmente o despertará depois

\footnotetext{
${ }^{25}$ Correio da Manhã, 25 ago. 1936, p. 9; Diário Carioca, 25, 27 e 28 ago. 1936, p. 8, 30 ago.1936, p. 19; Diário de Notícias, 25, 27 e 28 ago. 1936, p. 8, e 29 ago.1936, p.10; Jornal do Brasil, 25 ago. 1936, p. 25, 28 ago. 1936, p. 13, e 29 ago.1936, p. 35; O Jornal, 25 e 26 ago.1936, p. 5; Correio Paulistano, 2 out. 1936, p. 9,6 dez. 1936, p.16, e 17 mar.1937, p. 8; Correio de S. Paulo, 2 out.1936, p. 6; Folha da Manhã, 29 nov. 1936, p.16 e 5 dez. 1936, p.18; O Dia, 7, 12, 17 e 27 jan. 1937, p. 4; O Estado, 9, 10, 13 e 21 jan. 1937, p. 6; Diário de Pernambuco, 10 e 15 mar. 1939, p. 8, e 23 mar. 1939, p. 6; A Federação, 12 maio e 5 jun. 1937, p. 5; A Notícia, 26 jan. 1937, p. 10, 31 jan. 1937, p. 5; Jornal do Commercio, 26 maio 1939, p. 6 e 19 jun. 1939, p. 4; O Imparcial, 13 jul. e 26 set. 1939, p. 2, 29 set. e 9 out. 1939, p. 1.

${ }^{26}$ Jornal do Brasil, 29 ago. 1936, p. 35; Diário de Notícias, 25 ago.1936, p. 8; Diário Carioca, 30 ago. 1936, p. 19; A Federação, 12 maio 1937, p. 5.
} 
de assistir Bela (Drácula) Lugosi em Assassinado pela televisão". Sem dúvida, cópia descabida de trecho do release do filme oferecido pela sua distribuidora. Ao contrário dos EUA e de poucos países europeus, a aquisição de um televisor no Brasil dependeria de importação e de nada serviria além de decoração da sala de estar, afinal, eram inexistentes sinais de tevê no país. Ademais, o texto segue vazado em tom propagandístico: "Muitas pessoas ignoram o quanto tem progredido a televisão, porém, este filme as revelará o seu aperfeiçoamento". Vendia-se a noção de que bastasse o espectador assistir ao filme para se atualizar sobre os avanços da televisão. Noção, entretanto, oferecida com certificação técnico-científica: "Esta película que foi produzida sob a orientação de Milton M. Stern, uma notável autoridade sobre o assunto, apresenta de maneira autêntica o trabalho prático da televisão. Mostra-nos que ultrapassou as experiências preliminares e que já se pode ter em casa um aparelho de televisão" ${ }^{27}$ Com seu nome constante nos créditos do filme como Televison Tecnician, Stern patenteara, em 1934, dispositivo de varredura de imagem para a tevê mecânica. ${ }^{28}$

Chama a atenção que todo o material da imprensa ocupado em propagandear ou noticiar o filme Assassinado não reproduzisse nenhum fotograma da aparelhagem televisiva apresentada em cena do filme. Dado que tal fato se soma à percepção de que a divulgação do filme no Brasil foi realizada com material produzido pela distribuidora estadunidense, isso permite cogitar que, de um lado, igual estratégia fora adotada quando da promoção de Murder nos EUA, e que, de outro, a propagandeada exibição do aparelho de transmissão da tevê aberta fosse mesmo explorada amplamente, em ambos os países, como atrativo de público. Enfim, a curiosidade do espectador sobre o real funcionamento da TV somente seria saciada com o ingresso na mão.

A revista Cinearte se restringia a emitir uma avaliação telegráfica sobre o suspense: "O filme pode prometer alguma coisa interessante para os amantes de filmes policiais, mas é um filme comum. Cotação: Regular". Sem dúvida, Murder, tal como todos os chamados Filmes B, se desenrolava sob roteiro um pouco confuso, com cenas descuidadamente editadas, textos/diálogos rasos ou truncados e intepretações pouco elaboradas pelos atores. Mas, ainda assim, oferecia um bom suspense para a época; talvez até hoje. De qualquer forma, a avaliação da Cinearte não ressonaria junto ao grande público brasileiro, uma vez que Assassinado pela televisão entrara em cartaz na Cinelândia do Rio de Janeiro em agosto de 1936 e fora mantido em exibição nos cinemas de bairros cariocas até março de 1937. Em cinemas da cidade de São Paulo seguiu, também, em longa temporada, entre novembro de 1936 a março do seguinte ano. No correr de 1937 até meados de 1939, ganhava os cinemas em capitais de vários estados..$^{29}$

\footnotetext{
${ }_{27}$ Diário Carioca, 27 ago. 1936, p. 8. Ver também Jornal do Brasil, 28 ago. 1936, p. 13, Diário de Notícias, 31 ago. 1936, p. 10, e Correio de S. Paulo, 2 out. 1936, p. 6.

${ }_{28}$ Ver STERN, Milton M. Scanning device, 1934. Disponível em $<$ https://patents.google.com/patent/US2099872>. Acesso em 22 mar. 2020.

${ }^{29}$ Ver Diário de Notícias, 29 ago. 1936, p. 10, 22 abr. 1937, p. 8; Diário da Noite, 1 set. 1936, p. 4; Correio da Manhã, 1 set. 1936, p. 10; Folha da Manhã, 29 nov, 1-5 dez. 1936, p. 18; O Imparcial, 8 mar. 1938, p. 15. Sobre o lançamento do filme em outras localidades, ver as edições de vários jornais e revistas publicadas entre jan. 1937-out. 1939. Disponíveis no acervo da Hemeroteca Digital da Biblioteca Nacional.
} 
Como filme inscrito no gênero suspense, enquadrado no subgênero whodunit ${ }^{30}$, Murder by television é editado em três sequências. A primeira ocupada com cenas de apresentação da maioria dos personagens, inclusive destacando os interesses de alguns deles em relação ao invento televisivo enfocado. A segunda engloba cenas do quadro em que ocorre o assassinato, aliás, a mesma a exibir a aparelhagem real de transmissão de TV aberta. E, por fim, a terceira sequência a girar em torno da investigação policial para descobrir o assassino e sua motivação, terminando com a devida "virada na trama", como exigido pelo subgênero whodunit. No caso de Murder a autoria do crime é do insuspeito personagem Dr. Scofield, o qual é apresentado e mantido até o desfecho do suspense apenas como amigo do professor Houghland e de ilibada devoção à ciência. Ainda na sequência final, há cenas de humor a cabo do personagem mordomo Ling, já acima mencionado, e o da cozinheira negra Isabelle (Hattie McDaniel). Mas chistes e performances cômicas de ambos os personagens reproduzem preconceitos sobre imigrantes chineses e afrodescendentes a pulularem na sociedade estadunidense da época.

Na sequência intermediária, são exibidas cenas a focalizarem a recepção social oferecida pelo inventor aos convidados para acompanharem a demonstração televisiva na sua mansão, dentre eles, está o chefe de Polícia Nelson (Henry Mowbray). Essas são intermediadas com singela cena de romance, protagonizada pelo casal de namorados Richard Grayson e June Houghland. Ainda na segunda sequência, o anfitrião em conversa com convidado menciona a pressão sofrida para vender o seu invento, situação reforçada em breve cena seguinte. Nela, Houghland é procurado e atende, ainda durante a recepção social, o personagem Sr. Mendoza (Larry Francis), o qual - com única aparição no filme - se identifica como representante de interessados na compra do invento, dispostos a pagar qualquer valor. Com a recusa do professor, Mendoza o alerta que seus representados são "pessoas poderosas" e aconselha o inventor desistir da demonstração televisiva planejada.

Em seguida, com mais de 15 minutos de exibição do filme, tem início a cena com a transmissão de televisão aberta. Com rápido introito, informando ser ele o "proprietário da estação experimental ZY3, com sede em White Plains, Nova York, e emitindo por um canal de três quartos, intentando chegar a todos os EUA simultaneamente", Houghland inicia a sua transmissão, passando logo em seguida a televisionar a interpretação de uma canção por sua filha, como destacado bem mais acima. Ao levar o microfone até à filha e pianista, vê-se na tela a primeira exibição da imagem do aparelho de transmissão de tevê; como pode ser observado na figura 2. O aparelho, exibido em close, assim como noutras cinco partes da cena, é tão somente o Painel de Células Fotoelétricas, dispositivo necessário ao funcionamento do Flying Spot Scanner (FSS). Desenvolvido por Ulysses Sanabria e ao contrário da câmera de tevê que conhecemos, o FSS projeta uma fonte de luz brilhante que, gerada por lâmpada de arco, move-se sobre cada ponto da cena - os quais focados por disco Nipkow e lente - tem sua imagem, ao mesmo tempo, refletida e captu-

\footnotetext{
${ }^{30}$ De "who done it", estilo de narrativa que, vindo da literatura policial, se ampliou no cinema a partir dos anos de 1930, geralmente a trama se inicia com um assassinato, cuja solução fica a cargo de um detetive que se vê frente a pistas falsas, dificultando a investigação e causando dúvidas ao público em relação aos personagens, sendo a autoria do crime revelada no final, em regra, cometido por personagem insuspeito.
} 
rada por células fotoelétricas, produzindo, assim, o sinal de vídeo a ser transmitido.

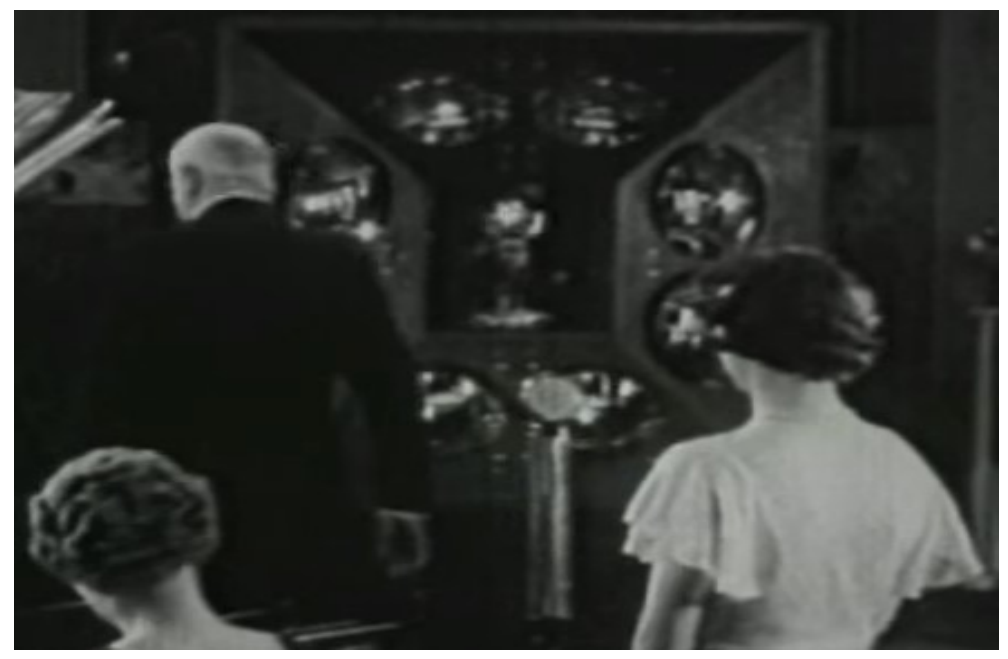

Figura 2. Painel de Células Fotoelétricas (PCF) em Murder by television.

Enfim, o dispositivo exibido na cena era apenas parte do FSS. Para oferecer ao público a unidade de dispositivos necessários à transmissão da TV mecânica, seria necessário que na cena de Murder fossem exibidos, além do Painel de Células Fotoelétricas, o próprio FSS, o amplificador de vídeo - como visualizado na figura 3 - além de serem dispostos em salas separadas e manuseados por diferentes profissionais; como observado no desenho de uma planta básica de emissora vislumbrado na figura 4 . Utilizado por emissoras estadunidenses de televisão operadas em caráter experimental em parte dos anos 1930, o FSS possibilitava apenas imagens de baixa resolução, no máximo de 60 linhas e 20 quadros por segundo. Portanto, longe da nitidez das imagens televisionadas na cena. Ademais, o funcionamento do aparelho se limitava a ambientes fechados e escuros, diferentemente da luminosidade presente no laboratório/estúdio do professor.

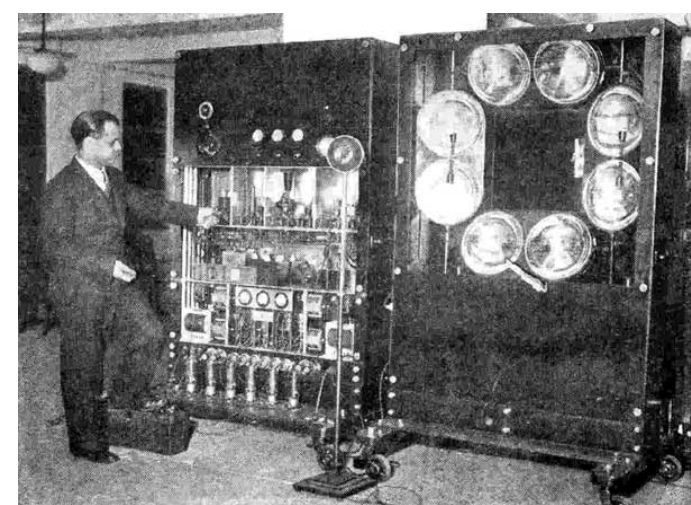

Figura 3. Ulysses Sanabia em frente ao PCF e amplificador.

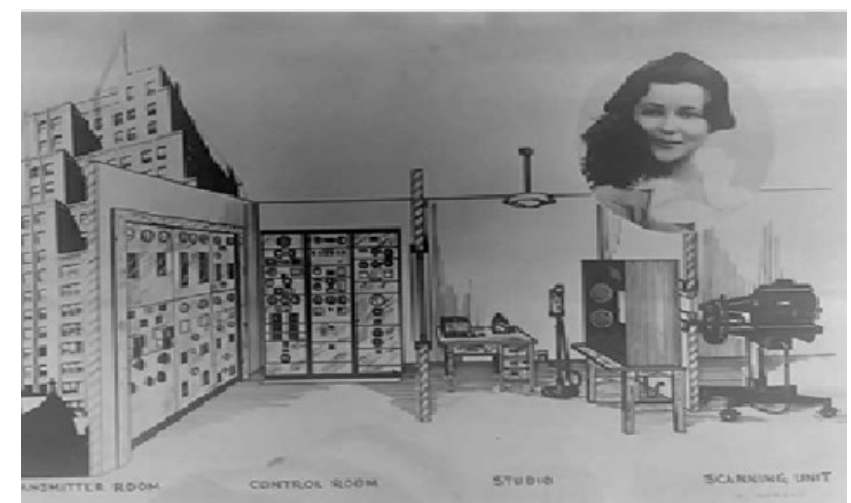

Figura 4. Planta básica de emissora de TV mecânica (1934). 
Além de exibir parcialmente a aparelhagem necessária à transmissão da tevê mecânica, o filme trazia à tela tecnologia que já se encontrava ultrapassada, diante dos avanços conquistados com relação à televisão eletrônica. Ao contrário, o televisor exibido na sala de estar da mansão de Houghland era cenograficamente montado bem diferentemente dos modelos fabricados no período, mantendo grande similaridade aos fabricados mais recentemente; como comparado nas figuras 5 e 6. De qualquer forma, a exibição do Painel de Células Fotoelétricas deveria causar, por si só, alumbramento ao grande público. Afinal, esse não dispunha de preciso conhecimento acerca do nível tecnológico alcançado pela tevê para que pudesse aquilatar a atualidade ou não do que lhes era oferecido na tela. Mas textos/diálogos e ações que compõem o enredo de Murder se revelam prenhes de visões e apreciações sobre a operação e o uso da TV aberta. E, obviamente, atravessadas por projeções sobre a possível expansão da TV nos EUA e na Europa.

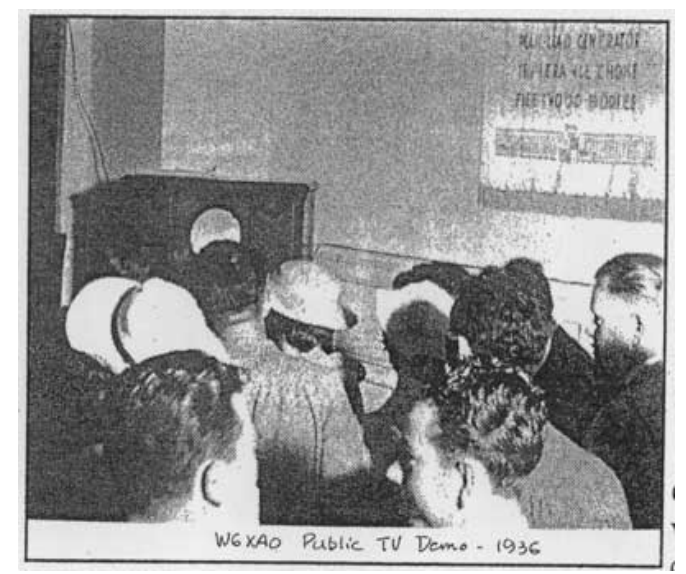

Figura 5. Demonstração de televisor (1936).

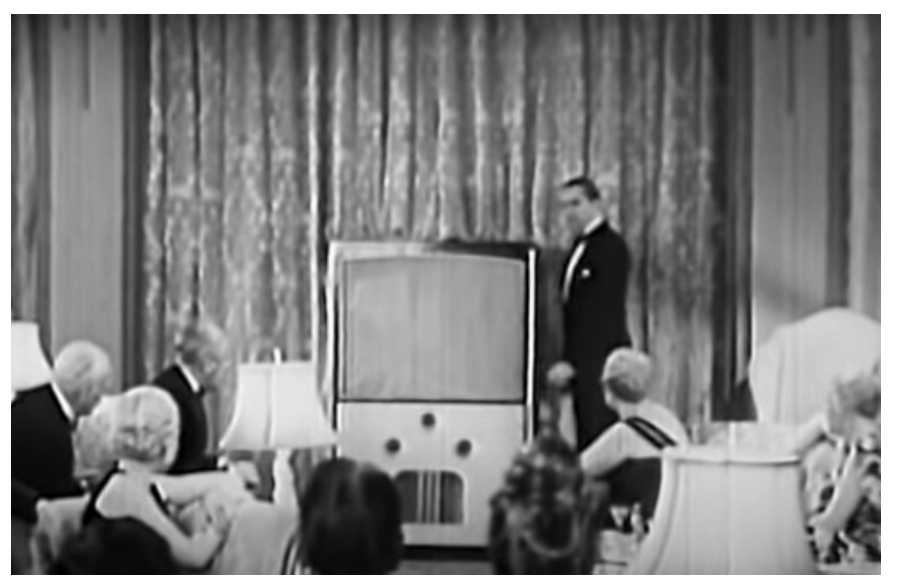

Figura 6. Televisor exibido em cena de Murder by television.

\section{Modelos de operação e o uso da tevê aberta}

Três tipos de modelos de operação e uso da tevê aberta são esboçados no decorrer de Murder/Assassinado. Dois deles se delineiam mais claramente em cenas da primeira e segunda sequências. São eles: o modelo comercial e o livremente operado pela sociedade. Na sequência derradeira, ambos são contrapostos a um terceiro modelo. Porém, esse é apenas sugerido na trama, ainda, assim, de maneira muito fluida. De qualquer forma, o trio de modelos são caracterizados com base em visões e apreciações sobre a televisão mais ou menos reinantes, à época, em círculos da ciência e tecnologia, de empresários do ramo da comunicação social, autoridades e organismos oficiais ocupados com esse setor. Todas, geralmente, calcadas sobre fatos e processos relativos a experimentos com o meio em termos de seu funcionamento e uso, envolvendo questões acerca da propriedade, operação e produção/veiculação de conteúdo, quer desenrolados nos EUA quer em alguns outros países europeus. Sem dúvida, visões e apreciações eivadas de parcialidades e/ou omissões socialmente interessadas sobre a operação e os usos da tevê aberta, muitas vezes engen- 
dradas com base na operação do rádio, que se achava em expansão nos EUA e noutros países, inclusive no Brasil.

Em cenas da primeira sequência, marcadas por reuniões de executivos da CMP Television e Continental Television, alguns elementos relativos ao modelo comercial de operação da televisão aberta são matizados. Assim, emissoras de tevê comerciais funcionam como empresas pautadas pela busca do lucro privado. Concorrem pela maior audiência possível - sendo a CMP posicionada, na trama, como líder na aderência do público. Se ocupam atavicamente na obtenção de inovadora tecnologia televisiva - como ilustra a busca atroz pelo invento de Houghland, uma vez que permitiria padrão de transmissão em 180 linhas, bem superior ao até então empregado, além de possibilitar transmissões em âmbito nacional. Necessitam de vultosas cifras para se manterem atualizadas tecnologicamente e bem posicionadas na concorrência como indicado pela proposta de 5 milhões de dólares oferecida pela Continental Television na compra da tecnologia disputada na trama. Em se tratando de operação comercial da transmissão de conteúdo televisivo, o espectador não teria dificuldade para concluir que vultosas somas somente seriam investidas em tal negócio caso tivessem o potencial para gerar lucros sobre o montante aplicado. Todavia, não há no filme nenhuma especificação que o lucro viesse da comercialização de horário à publicidade. Talvez o roteirista contasse que o espectador conhecesse e, assim, estendesse a geração de tal lucro já obtido pelo rádio comercial à nascente televisão, uma vez que aquele tipo de operação radiofônica se firmava nos EUA. Relação que ia se tornando conhecida aos brasileiros, dado o Brasil experimentar igual processo no setor da radiofonia, ainda que em ritmo bem menos intenso em comparação ao daquele país norteamericano.

E, por fim, emissoras comerciais de tevê competiam, também, por profissionais especializados para o funcionamento do meio - segundo comentário de executivo da Continental aventando dificuldades que o professor Houghland encontraria caso quisesse transmitir regularmente programação. Sem, contudo, acentuar a diferença entre o organograma voltado à geração e transmissão de conteúdos televisivos e o direcionado à produção desses. Aliás, não consta na primeira sequência do filme nenhuma menção aos gêneros dos programas produzidos e/ou veiculados pelas emissoras comerciais de televisão, quesito somente destacado, na segunda sequência, em discurso de Houghland, ainda, assim, com uma alusão genérica à natureza da programação veiculada.

O modelo de operação almejado por Hougland começa a ser esboçado em conversas decorridas em cenas da recepção social realizada na mansão dele. O professor informa, primeiro, a existência de "uma comissão para assegurar o direito de utilizar a sua tecnologia nos EUA e no estrangeiro, para, logo, [poder] expandi-la". Assim, é indicado que o inventor pretende que sua tecnologia seja livre e gratuitamente utilizada por televisões abertas em todos os países, alheia a interesses específicos de empresários ou governantes. Posicionamento altruísta do personagem ilustrado, na primeira sequência, pela informação de sua recusa em patentear o seu invento ou comercializá-lo, além de reforçado, em breve cena da segunda sequência, quando ele é procurado pelo Sr. Mendonça. Depois, noutra conversa com convidados, Houghland expressa sua alta expectativa de que a TV funcione com um bem maior à vida 
humana: "Espero demonstrar que a televisão é ainda o maior passo que demos na preservação da Humanidade. Isso fará da Terra um paraíso. Mostrará coisas novas. Uma visão do paraíso que sempre imaginamos, mas nunca vimos". Positividade esperançosa a reativar platitudes lançadas ao longo da história quando da criação e chegada de um novo meio de comunicação social na vida social, como ocorrera, bem antes à produção do filme, com a revista ilustrada e o cinema e, mais proximamente ao momento da elaboração do suspense, com o rádio.

Em seu discurso, proferido na cena de sua transmissão televisiva, Houghland, entretanto, expressa uma crítica social com relação ao uso que era feito da TV: “Nós os afortunados que temos televisores, consideramos [a televisão] apenas uma novidade. E se não fizermos nada, sintonizaremos em qualquer programa que estiver sendo emitido". E seguia com breve histórico sobre o avanço tecnológico: "Devido a obstáculos quase intransponíveis para [se obter] as frequências requeridas à alta fidelidade das imagens, as emissões [televisivas] eram limitadas. Mas me satisfaz dizer-lhes que esses obstáculos foram superados. Foi um triunfo da ciência". E retomando a crítica social, o inventor contrapõe o seu almejado modelo de operação e uso da tevê aberta ao modelo comercial: "Mas enquanto ele [o triunfo das transmissões televisivas] não satisfazia a nada, sendo apenas uma diversão, pensei que a televisão devesse ser algo mais do que outra forma de entretenimento". Por fim, transmite no vídeo, ao vivo e sucessivamente, imagens cotidianas de Paris, Londres e de cidade da China. Ao intentar mostrar cenas do continente africano, comenta: "A África é um lugar que sabemos muito pouco. Os nativos da África, faz anos, se relacionam indiretamente... com... nossa... guerra... civil..." - fala entrecortada em razão de o personagem estar sob o efeito da emissão do "raio mortal".

Com as imagens televisionadas e os textos/discursos de Houghland, fica evidente que a missão pretendida à TV aberta é a da divulgação do conhecimento que sirva ao entendimento entre os povos e à harmonia mundial. Modelo a ser investido, mantido e acompanhado, entretanto, por membros de elite social e/ou entusiastas da chamada alta cultura universal. Configuração social destacada no discurso de Houghland com a menção aos "afortunados que têm televisores" - em alusão ao preço impeditivo do aparelho a segmentos sociais mais populares no período -, além de reforçada visualmente pelo rico vestuário dos convidados a acompanhar o evento e em menções às atividades profissionais desses no decorrer da trama. "Afortunados" contrapostos aos subalternos Ling e Isabelle que - mordomo e cozinheira da família Houghland - são vistos, em emblemático take da cena da demonstração televisiva, a espiarem, da soleira da porta da copa, o televisor em funcionamento disposto na sala de visitas da casa de seus patrões. Enfim, uma televisão aberta dirigida e mantida por gostos de uma elite sociocultural, a qual, de resto, esperava que ela fosse assistida/consumida por segmentos sociais populares tomados como necessitados de instrução afinada à educação e cultura calcadas em princípios/valores elitistas.

O terceiro modelo de operação e uso da tevê aberta, como adiantado acima, é antes sugerido do que caracterizado no enredo do filme, mas identificado como sendo da ordem do "governo estrangeiro" ao qual o Dr. Scofield serve como agente secreto. Se o nome do país estrangeiro cujo governo tinha 
interesse em se apossar da tecnologia televisiva de Houghland não é explicitado na cena final - quando se tem revelado a autoria do assassinato, a maneira como ele fora realizado e, por fim, a condição de agente secreto do Dr. Scofield -, o roteiro oferece um elemento em que é oferecida uma pista à identificação daquele governo - pouco explícita, contudo. Na cena tem-se a exibição, em close de onze segundos, de telegrama como prova de que o assassino agia como espião de governo externo - apresentado pelo personagem Arthur Perry, já identificado na trama, também, como agente do FBI. Nos primeiros segundos do close, se vê exibido um texto vazado em código, depois, emerge na tela sua versão traduzida: "A negociação foi cancelada, a menos que você obtenha o impresso [do segredo] antes que Houghland conclua a demonstração, se necessário, use medidas extremas para obter resultados. J.V.S." Ordem que se deve pensar fora decidida após tentativa frustrada do personagem Sr. Mendonza em comprar o segredo da tecnologia inventada pelo professor.

Parênteses se fazem necessários. O estudioso da televisão Toby Miller identifica as iniciais assinadas no telegrama como referentes ao nome completo de Stalin, ou seja, Josef Vissarionovitch Stalin. ${ }^{31}$ Leitura possível, porém Miller não fornece nenhuma explicação acerca de possível motivo de o enredo de Murder oferecer tão fluida pista ao espectador para identificar de qual "governo estrangeiro" o Dr. Scofield estava a serviço. Mas, ao se considerarem elementos da trama e acontecimentos interrelacionados ao sistema de produção/distribuição cinematográfica e à política externa dos EUA no período, pode-se lançar mão de uma explicação bastante plausível ao fato de o roteiro do filme evitar explicitar o nome do governante russo no telegrama.

De início, dois elementos do enredo devem ser considerados: Viena como a cidade em que o telegrama fora emitido - como se pode ler no seu cabeçalho quando a correspondência é visualizada em close - e a informação do Dr. Scofield de que, tão logo terminasse a demonstração televisiva, ele viajaria a Berlim para participar de um congresso de neurologia - como ouvida em cena da primeira sequência do suspense. Assim, deve-se ter em conta que a suposta ordem dada por Stalin fora expedida por telegrama emitido da capital austríaca, possivelmente como estratégia a despistar a atenção do serviço de inteligência dos EUA. Coisa factível. Afinal, Viena contava, nos anos 1930, com intensa movimentação de agentes secretos de países ocidentais e da URSS - com os primeiros espionando o governo Stalin e apoiarem sublevações contra esse, os segundos, vigilantes à espionagem ocidental e de olho na Alemanha nazista. ${ }^{32}$

No entanto, há que se ponderar que, para melhor permitir ao espectador valer-se da fluida pista fornecida no telegrama para concluir que o Dr. Scofield servia ao governo de Stalin, o enredo poderia tranquilamente nomear a capital soviética ou qualquer outra cidade da URSS como localidade de origem da emissão da mensagem. À época, o recebimento de um telegrama ori-

\footnotetext{
31 Cf. MILLER, Toby. Televison studies: the basics. New York: Routledge, 2010. Disponível em $<$ https://ayomenulisfisip.files.wordpress.com/2015/08/television-studies-the-basics>. Acesso em 18 out. 2019. 32 Ver ANDREW, Christopher and ELKNER Julie. Stalin and foreign intelligence. In: SHUKMAN, Harold (ed.). Redefining Stalinism. London-Portland: Frank Cass, 2003, e GRIBBLE, Richard. United States recognition of Soviet Russia: 1917-1933. American Catholic Studies, v. 119, n. 4, Villanova, 2008. Disponível em <https://www.jstor.org/stable/44195182?seq=1>. Acesso em 22 mar. 2020.
} 
ginário da URSS não despertaria, por si só, nem mais nem menos atenção da inteligência dos EUA do que um expedido da Áustria. Isso por conta de que, a partir de 1933, as relações diplomáticas entre Washington e Moscou eram retomadas, em decorrência do reconhecimento do governo soviético pela gestão de Roosevelt. Tal situação gerara uma série de acordos de trocas comerciais e acordos de cooperação entre ambos os países. Dentro desse quadro, o enredo poderia contribuir ainda mais com o espectador para que esse percebesse a relação do Dr. Scofield e o governo de Stalin simplesmente indicando que o congresso em que o cientista participaria - a servir, na trama, como álibi previamente planejado para despistar o seu ilícito a ser realizado - ocorreria em território soviético.

Ademais, Viena ganhava destaque na cena internacional, repercutida na imprensa tanto dos EUA como do Brasil, não em razão da intensa ação de espionagem que nela ocorria, mas, sim, por conta de interesses e ações do governo de Hitler em anexar a Áustria à Alemanha - o que de fato ocorrera em 1938. Parte da imprensa estadunidense, ao lado de notícias sobre o nazismo alemão e fascismo italiano, difundia especulações acerca da configuração que os EUA teriam caso viessem a seguir às políticas vigentes na Alemanha e Itália. Clima que, aliás, servira a Sinclair Lewis para lançar, em 1935, a novela It can't happen here, calcada numa distopia satírica em que um fascista ascende à Presidência dos EUA. Tornada rapidamente best-seller, adaptada com sucesso ao teatro, em 1936, a novela de Lewis tinha a sua versão cinematográfica produzida pela Metro, naquele ano; plano, no entanto, abandonado pela companhia sob alegação de problemas nos custos da produção. Contudo, o real motivo de tal desistência vinha a público naquele mesmo momento: Louis B. Mayer, chefe da Metro, recebera alerta de agentes da Administração do Código de Produção Cinematográfica que o filme encontraria problemas no mercado alemão por conta de que "o roteiro era antifascista e repleto de elementos perigosos". Ficava evidente a interferência da política externa dos EUA e Alemanha nazista na produção/distribuição do cinema hollywoodiano. Poucos anos depois, a sátira The dictador de Charles Chaplin (1940, United Artists - O grande ditador, maio de 1942) receberia manifestações contrárias de Hitler ainda quando era filmada, tendo, depois, sua distribuição vetada na Alemanha e em países tributários do nazifascismo. ${ }^{33}$ Sob o discricionário Estado Novo, liderado por Getúlio Vargas e inicialmente simpático ao nazifascismo, o público brasileiro somente assistiria ao filme de Chaplin perto do ditador declarar guerra ao Eixo, integrando às Forças Aliadas, segundo acordos com os EUA. ${ }^{34}$

Assim, os elementos até aqui levantados permitem considerar que o roteiro original de Murder muito possivelmente identificasse o personagem Dr. Scofield como agente a serviço do governo de Hitler; porém, no decorrer das filmagens, tal referência fora suprimida, sem a devida reparação ou ajuste de elementos identificados com a possível primeira versão do roteiro. Isso por conta de que os agentes produtores do filme talvez intuíssem ou tivessem sido informados sobre provável embaraço que o filme poderia colher com o gover-

\footnotetext{
33 Ver GREEN, Jonathon and KAROLIDES, Nicolas J. Encyclopedia of censorship. New York: Facts On File, Inc., 2005. Disponível em <http://www.encyclopedias.biz/dw/Encyclopedia\%20of\%20Censorship.pdf>. Acesso em 23 mar. 2020.

${ }^{34}$ Ver TOMAIN, Cássio S. Janela da alma: cinejornal e o Estado Novo. São Paulo: Annablume, 2006.
} 
no de Hitler, uma vez que a trama aludiria ao desabonador uso que tal governante faria do então novo meio de comunicação social, além de ser mandante de assassinato para obtenção de tecnologia televisiva. Tal hipótese é plausível ao se considerar que, primeiro, quando da elaboração do roteiro e filmagens daquele suspense, a Alemanha, ao lado da Grã-Bretanha, era conhecida pelos significativos avanços tecnológicos da televisão e por operar regularmente TV aberta. E não era o caso da URSS, cujo avanço da sua televisão, operada experimentalmente desde 1931, contara com a importação, em 1938, de tecnologia e aparelhagem televisiva dos EUA. ${ }^{35} \mathrm{E}$, em segundo lugar, não era nenhum segredo o fato de que Hitler testava a nova mídia à serviço de sua sistemática propaganda política desde 1935, via criação de salas coletivas de recepção televisiva; estratégia confirmada com o televisionamento, ao vivo, das Olimpíadas de Berlim de 1936. Ademais, devido, também, às estáveis relações diplomáticas Washington/Moscou, agentes da produção de Murder talvez tivessem optado em oferecer a fluída pista da trama a indicar Stalin como o mandante do assassinato de Houghland. Forma encontrada para se precaverem de prováveis obstáculos à distribuição do filme em território soviético; caso essa viesse a ocorrer. Por fim, incoerências e inconsistências no enredo de Murder, como até descritas nos parágrafos acima, permaneceram na edição final do filme por conta da comumente precariedade na produção de típicos Filmes B. Ressalte-se, roteiros confusos, cenas pouco cuidadas, textos rasos e truncados que não geravam pejo aos agentes produtores de Filmes B, nem afetavam as suas bilheterias. Murder by television não seria exceção.

De qualquer maneira, o fato de o personagem Dr. Scofield atuar como agente secreto de um "governo estrangeiro", portanto, não de empresa comercial de TV estrangeira, permite a ilação de que aquela tecnologia era buscada para ser aplicada em tevê aberta como serviço público operado pelo poder público; como já era o caso da televisão alemã e da britânica, embora as duas mantivessem grande distância em termos de uso do meio. A primeira era operada como televisão de governo, colocada a serviço da opinião única; porém não era outro o uso que Stalin ia fazendo da nascente televisão, assim como dos demais meios de comunicação. E a segunda seguia conduzida pelo Estado a serviço da sociedade, mediante representações de segmentos dessa e distante, pelo menos estatutariamente, ao mando de governos. Logo, o modelo de tevê aberta a ser operada pelo "governo estrangeiro" a que servia o Dr. Scofield era apresentado, metaforicamente, como mortal tanto ao modelo comercial quanto ao idealizado pelo professor Houghland. Não por acaso, na trama, a sanha do "governo estrangeiro" em se apossar de inovadora tecnologia termina com o assassinado do seu inventor. Forma violenta de obtenção da tecnologia a impactar inclusive personagens vinculados às duas emissoras comerciais da trama, ainda que eles pretendessem assenhorar-se do invento por vias ilícitas. E, também, não é por acaso que o "raio mortal de frequência interestelar" fora emitido via aparelhagem televisiva. Elemento a performar que o meio em si não é um mal, mas, antes, o seu uso e o conteúdo por ele emitido. E não é despropositadamente que, na trama, o raio mortal antigira a cabeça de

\footnotetext{
35 Ver PAULU, Burton. Radio and television broadcasting in Eastern Europe. Minneapolis: University of Minnesota Press, 1974. Disponível em <https://www.lboro.ac.uk/subjects/communication-media/rese arch/research-projects/screening-socialism/television-histories/tvintheussr/>. Acesso em 10 jan. 2020.
} 
Houghland. Metáfora para a inculcação ideológica que conteúdos televisivos pudessem promover contra a consciência individual.

A saída de tal perigo, entretanto, não deixa de ser oferecida no enredo de Murder: o monitoramento da tevê aberta pelo Estado. Ente políticoadministrativo oferecido para se impedir que o meio funcionasse como emissário da opinião única - TV de governo - ou a servir exclusivamente aos interesses do dinheiro privado - a TV comercial -, mas, também, sem se fiar no modelo livre e altruísta idealizado pelo inventor da trama. Se, na segunda sequência do filme, o Estado é posicionado como mero espectador da transmissão televisiva por Hoghland - como visto no take da cena em agentes do governo acompanham de Washington o televisionamento realizado pelo professor -, no final do suspense, o papel do Estado com relação ao meio ganha outro contorno. Na cena derradeira em que o personagem Arthur Perry informa a sua missão secreta para o FBI em monitorar o trabalho do inventor, pode ser entendida como uma metáfora relativa ao necessário acompanhamento de perto da nascente televisão pelo Estado. Tarefa a ser desempenhada por conta de que a televisão, justamente por suas potencialidades, pudesse se transformar em arma incontrolável contra a sociedade nas mãos quer de desmedidos empresários, a agirem pela lógica do "tudo pelo lucro privado", quer de governantes, em busca do poder personalista e/ou totalitário. Males a serem impedidos, por sua vez, com o controle do setor via regulamentação legal, posto a noção de que o setor deixado a si mesmo colocaria em risco ou aniquilaria uma sociedade calcada tanto no desejo da livre e justa concorrência quanto do respeito às liberdades individuais. Elementos ideológicos tão caros ao imaginário da sociedade dos EUA, os quais pululavam no cinema de Hollywood, na tentativa de, ao mesmo tempo, reforçá-los junto à sociedade estadunidense e para autodefinição dos EUA frente ao público de tantos países quanto os seus filmes fossem exibidos. E o assassinato em Murder conota os limites do voluntarismo ou altruísmo que, de resto, performados na trama como idealistas e ingênuos, pudessem ser projetados à operação e ao uso da televisão. Enfim, valores insuficientes para evitar e combater os perigos a rondarem a operação e o uso de tão poderoso meio à comunicação social.

A noção e projeção sobre o modelo de operação da tevê aberta performadas em Murder guardam nítida consonância com a então recém-aprovada Communications Act, de 1934. Surgida como resposta de Roosevelt ao setor de telecomunicações, tal legislação englobava quase toda a Radio Act, vigente desde 1927, e previa a regulamentação de todo aquele setor - compreendido, à época, a comunicação ponto a ponto (telegrafia e telefonia) e a radiodifusão de conteúdo (rádio e televisão). Assim, era assegurada ao Estado a propriedade do espaço eletromagnético, cuja exploração se daria por particulares mediante concessões de serviço público, vetando-se o monopólio no setor de radiodifusão de conteúdo, além de definir que, ao menos em parte, lee devesse atender aos interesses da sociedade. Ademais, aquela legislação criou a Federal Communications Commision (FCC). Estabelecida como agência assessora do Congresso, funcionando até os dias de hoje, a FCC se incumbiria de zelar pelas normas de regulamentação e monitorar a veiculação de conteúdo do setor.

Aos espectadores brasileiros em geral, a vinculação da mensagem de Assassinado pela televisão com a política dos EUA voltada à comunicação social eletrônica talvez fosse mais difícil de ser percebida do que por seus congêne- 
res estadunidenses, embora, sob o governo de Getúlio Vargas, quer em seu período provisório quer constitucional, o setor radiofônico seguisse trilha assemelhada à aberta pelo governo Roosevelt. Contudo, o governante dos EUA não cairia na tentação de utilizar aquela mídia, nem a nascente televisão, a serviço de um poder discricionário como o fizera o governante brasileiro durante o Estado Novo, ditadura que, engendrada em ideais nazifascistas, não percebera que a mensagem de Assassinato continuava a ser veiculada nos cinemas brasileiros até 1939 .

Artigo recebido em 14 de setembro de 2020. Aprovado em 30 de novembro de 2020. 